\title{
The isolation and amplification of full length cDNA of oleosins from oil palm (Elaeis guineensis Jacq.)
}

\author{
Shariza Binti Jamek ${ }^{1}$, Ngoh Gek Cheng ${ }^{2 \star}$ and Chuah Teon Guan ${ }^{3}$ \\ ${ }^{1}$ Faculty of Chemical and Natural Resources Engineering, Universiti Malaysia Pahang, Lebuhraya Tun Razak, 26300, \\ Kuantan, Pahang, Malaysia. \\ ${ }^{2}$ Department of Chemical Engineering, Faculty of Engineering, University of Malaya. \\ ${ }^{3}$ Department of Chemical and Environmental Engineering, Faculty of Engineering, Universiti Putra Malaysia.
}

Accepted 11 March, 2010

\begin{abstract}
This study focused on the isolation and amplification of the cDNA clone of oleosin from oil palm. The oil palm cDNA library constructed from the kernel tissues 10 weeks after anthesis (WAA) produced a clone of p01A containing partial $563 \mathrm{bp}$ sequence of oleosin. The polymerase chain reaction for the rapid amplification of CDNA ends (RACE-PCR) was performed to obtain full length cDNA of oleosin from the RNA transcripts using forward gene-specific primers that is, primer Oleo 3 . The product was then cloned into PCR 4 TOPO vector and subjected to sequencing using M13 forward and reverse primers. The end-to-end PCR method was performed to amplify the complete cDNA sequence of oleosin and it produce a $750 \mathrm{bp}$ PCR product. The BLAST results showed that the cDNA from oil palm kernel isolated exhibited high similarities with low molecular weight isoforms of oleosin cDNA from crops like rice, maize and barley.
\end{abstract}

Keywords: Oleosin, oil palm, cDNA, RACE-PCR, gene-specific primers.

\section{INTRODUCTION}

Oil palm (Elaeis guineensis Jacq.) is a perennial tree crop and has been known as the highest oil yielding crop compared to many other oil crops. The typical yield of oil palm is about 3.68 tonnes of oil per hectare compared to rapeseed of 0.59 , sunflower seed of 0.42 and soybean of 0.36 (Davidson, 2006). Estimated $80 \%$ of palm oil goes into food and $20 \%$ is used in the non-food sector. Like all oils, triacylglycerols (TAGs) are the major component in palm oil with $95 \%$ of the oil comprising of a mixture of TAGs. Each TAG is made up of a glycerol backbone esterified with three fatty acids (Sambanthamurthi et al., 2000).

Oil bodies are subcellular organelles found in many plant species and consist of a matrix of triacylglyceride (TAG) covered by a layer of phospholipids, which is embedded by a set of water insoluble (15-26 kDa) proteins called 'oleosins' (Murphy, 1993). Oleosins has

*Corresponding author. E-mail: ngoh@um.edu.my. Tel: +6-037967-6879. Fax: +6-03-7967-5319. been proposed to act as a recognition signal for the specific binding of lipase to oil bodies (Hsieh and Huang, 2004). In recent years, oleosins have received considerable attention, particularly in relation to oil body biogenesis and their structural role in stabilizing triacylglycerol/ cytosol oil body interface (Tzen and Huang, 1992). Therefore, it is necessary to understand the correlation of oleosins with the lipolytic action of lipase which consequently decreases the quality of palm oil. Basic information regarding the molecular aspects of oil palm oleosins will be useful for verifying the proposed role of oleosins as a receptor for lipase binding (Murphy, 1993; Huang, 1996; Murphy and Vance, 1999). Besides oleosin manipulation, there was also interest in oleosins as carriers for the expression and purification of recombinant pharmaceutical peptides and industrial enzymes (Rooijen and Moloney, 1995; Li et al., 2002). Hence, the objective of the study is to isolate and amplify the oleosin cDNA sequence as it is an essential step in obtaining basic information regarding the molecular aspects of oil palm oleosin and to give possible biotechnological application in other potential industries. 


\section{MATERIALS AND METHODS}

\section{Materials}

The chemical used were of molecular biology grade. Different tissues used for the RNA extraction were from oil palm ( $E$. guineensis Jacq. tenera variety). The oil palm kernels at $10^{\text {th }}$ week after anthesis (WAA) were collected from a plantation in Malaysian Palm Oil Board (MPOB), Bangi, Selangor, Malaysia. All the plant materials were cleaned and dissected before being frozen in liquid nitrogen and then stored at $-80^{\circ} \mathrm{C}$ until needed. The kernel cDNA library of 10 WAA E. guineensis was obtained from Biochemistry Laboratory, Malaysian Palm Oil Board.

\section{RNA extraction}

The method employed is a modification of Prescott and Martin, (1987). Five grams of dissected oil palm kernel tissues (10 WAA) were ground into fine powder in a liquid nitrogen- filler mortar. The ground tissues were then transferred into RNase-free beaker and $30 \mathrm{ml}$ of extraction buffer $(50 \mathrm{mM}$ Tris $-\mathrm{HCl} \mathrm{pH} 9.0,150 \mathrm{mM}$ lithium chloride ( $\mathrm{LiCl}$ ), $5 \mathrm{mM}$ ethylenediaminetetraacetic acid (EDTA) $\mathrm{pH}$ $8.0,5 \%(\mathrm{w} / \mathrm{v})$ sodium dodecylsulfate (SDS), $2 \mathrm{mM}$ aurin tricarboxylic acid and $0.4 \%$ 2-mercaptoethanol) was added. Equal volume of phenol/ chloroform [50:50 (v/v)] was added to the beaker. The buffer, tissues and the phenol/chloroform mixture was homogenized with polytron for about $2 \mathrm{~min}$. The mixture was then transferred into a tube and centrifuged at $25^{\circ} \mathrm{C}$ for $30 \mathrm{~min}$ at $13,000 \mathrm{rpm}$ to separate the mixture into two phases. The top aqueous phase was transferred to a tube and 24:1 (v/v) chloroform/ ispamyl alcohol was added to it. The mixture was vortexed extensively for $5 \mathrm{~min}$ before being centrifuged into separate phases. The top aqueous phase was once again transferred with addition of $8 \mathrm{M} \mathrm{LiCl}$ to a final concentration of $2 \mathrm{M} \mathrm{LiCl}$. The mixture was placed at $4^{\circ} \mathrm{C}$ for $24 \mathrm{~h}$.

The following day, the mixture was centrifuged at $4^{\circ} \mathrm{C}$ at 13,000 rpm for $30 \mathrm{~min}$ to pellet the nucleic acids. The aqueous phase was discarded and $2.5 \mathrm{ml}$ of $2 \mathrm{M} \mathrm{LiCl}$ was added to the pellet. The procedure was repeated the second time except that $2.5 \mathrm{ml}$ of cold RNase-free distilled water was added to the remained pellet. The mixture was agitated until the pellet dissolved. $8 \mathrm{M} \mathrm{LiCl}$ was added to a final concentration of $2 \mathrm{M} \mathrm{LiCl}$. The mixture was then stored overnight at $4^{\circ} \mathrm{C}$. The mixture was palletized to RNA at $13,000 \mathrm{rpm}$ the next day. The same procedure was repeated twice as before. The RNA pellet was dissolved in $400 \mu$ of cold RNase-free distilled water.

The total RNA was quantified by spectrophotometer at wavelength of 230,260 and $280 \mathrm{~nm}$. The RNA was also separated on agarose gel to determine its quality. The yield of the total RNA extraction was calculated by:

$$
Y=\frac{C \times V}{M}
$$

Where, $Y$ is the yield of total RNA extract $(\mu \mathrm{g} / \mathrm{g}), C$ is the concentration of total RNA $(\mu \mathrm{g} / \mathrm{g}), V$ is the final volume of RNA water added $(\mu \mathrm{l})$ and $\mathrm{M}$ is the tissue weight $(\mathrm{g})$.

\section{RNA isolation and treatment}

The methods employed were based on Ausubel et al. (1994) and Maruyama and Sugano, (1994). The RNA treatment was carried out according to the protocol provided by the GeneRacer ${ }^{\mathrm{TM}}$ Kit (Invitrogen, USA) which involved three main steps; dephosphorylation of RNA, removal of mRNA cap structure and ligation of RNA Oligo to decapped mRNA. This RNA treatment was only applied for 5' rapid amplification of CDNA ends (RACE) template.

Reverse transcription of mRNA and rapid amplification of cDNA ends polymerase chain reaction (RACE-PCR)

The ligated RNA sample produced previously was used for the reverse transcription of RNA. The resulted mixture from the reverse transcription was then stored at $-20^{\circ} \mathrm{C}$ for rapid amplification of CDNA ends (RACE-PCR).

A 5' RACE-PCR was carried out using GeneRacer ${ }^{T M}$ kit to obtain a 5'-end of the oleosin cDNA using forward gene-specific primer (Oleo 3 ) designed based on the partial sequence of oleosin from the cloning. Subcloning of DNA by inserting into $\mathrm{pCR}^{\circledR} 4$-TOPO vector was performed using TOPO TA Cloning ${ }^{\circledR}$ Kit for Sequencing (Invitrogen, USA). The sequencing of plasmid clones was performed using ABI PRISM ${ }^{\mathrm{TM}}$ Dye Terminator Cycle Sequencing Ready Reaction Kit (Applied Biosystems Inc., USA) and an ABI PRISM 377 automatic DNA sequencer.

Two independent 5' RACE-PCR experiments were performed using the forward gene-specific primers (Oleo 8 and 9) that had been designed based on a contig sequence. The PCR products were run on agarose gel electrophoresis with the GeneRuler DNA Ladder (MBI Fermentas, USA) for comparison purpose.

The end-to-end PCR method was performed to amplify the complete cDNA sequence of oleosin. Three end-to-end PCR were carried out by combining the forward and reverse gene-specific primers designed based on the extended consensus sequence; Oleo13A and 15B, Oleo 15A and 15B, and Oleo 16A and 15B. The end-to-end PCR reaction was carried out in a total volume of $25 \mu \mathrm{l}$ containing $0.5 \mu \mathrm{l}$ of deoxynucleotides (dNTP) mix, $0.5 \mu \mathrm{l}$ of cDNA template, $0.5 \mu \mathrm{l}$ of reverse and forward primers, $3.0 \mu \mathrm{l}$ of $10 \times$ PCR buffer with magnesium chloride $\left(\mathrm{MgCl}_{2}\right), 0.5 \mu \mathrm{l}$ of Platinum High Fidelity Taq DNA Polymease $(5 \mathrm{U} / \mu \mathrm{l}), 1.25 \mu \mathrm{l}$ of dimethyl sulfoxide (DMSO) and $18.25 \mu \mathrm{l}$ of distilled water. Thirty six PCR cycles were performed as follows: 35 cycles; $94^{\circ} \mathrm{C}$ for $30 \mathrm{~s}, 60^{\circ} \mathrm{C}$ for $30 \mathrm{~s}$ and $72{ }^{\circ} \mathrm{C}$ for $90 \mathrm{~s}$ followed by 1 cycle of $72^{\circ} \mathrm{C}$ for $7 \mathrm{~min}$.

\section{Sequence analysis}

Partial sequences obtained from automated sequencing were displayed using Cromas software (Version 1.45). Vector sequences at both 5' - ends of sense strand and 3'-end of antisense strand was removed. All partial sequences obtained were aligned using OMIGA software (Version 2.0) to produce a contiq sequence of oil palm oleosin. The full length of cDNA sequence of oleosin was then compared for sequence similarities with other sequences in database using BLAST (Basic Local Alignment Search Tool) program (Altschul et al., 1997) at NCBI (National Center for Biotechnology Information). The BLAST program used involved both the blastn and blastx.

\section{RESULTS AND DISCUSSION}

\section{Isolation of the full length cDNA clone of oleosin from oil palm kernel}

The yield obtained from the total RNA isolated from 10 WAA was $300 \mu \mathrm{g} / \mathrm{g}$. The oil palm cDNA library constructed from the kernel tissues at 10 WAA produced a clone pO1A containing the partial $563 \mathrm{bp}$ sequence of oleosin. This clone had a poly A tail at the 3'-end. Hence, 5' RACEPCR was performed to obtain the full length CDNA of 
(a)
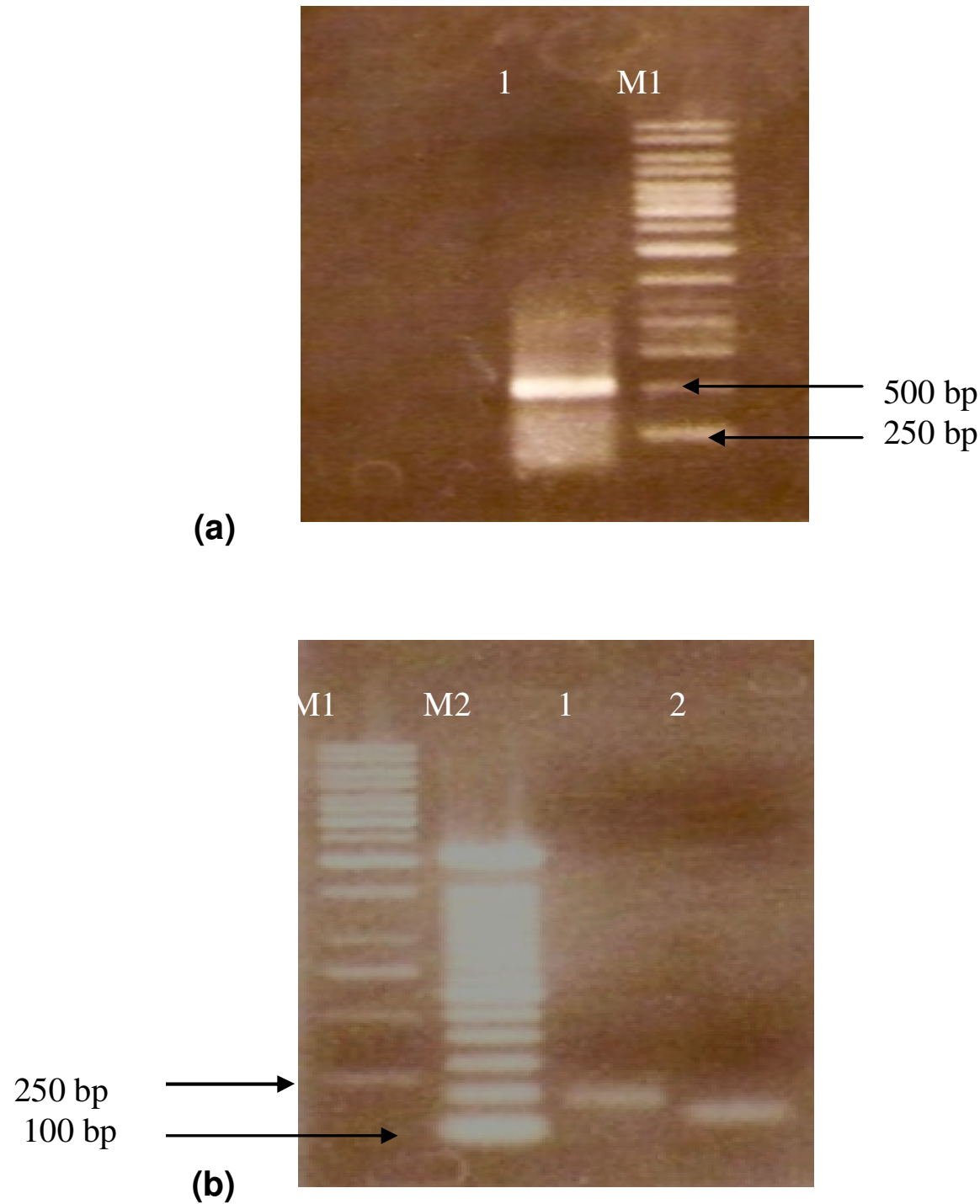

Figure 1. Agarose gel electrophoresis of PCR fragments amplified from oil palm kernel using primers specific to the coding region of the oleosin cDNA. (a) Lane 1: $500 \mathrm{bp}$ PCR product (Oleo 3) and Lane M1: $1 \mathrm{~kb}$ GeneRuler DNA ladder. (b) Lane 1: $200 \mathrm{bp}$ PCR product (Oleo 8), Lane 2: $150 \mathrm{bp} \mathrm{PCR} \mathrm{product} \mathrm{(Oleo} \mathrm{9)} \mathrm{and} \mathrm{lane} \mathrm{M1:} 1 \mathrm{~kb}$ GeneRuler DNA ladder and lane M2: 100 bp GeneRuler DNA ladder.

oleosin from the oil palm kernel RNA transcripts.

The initial amplification using primer Oleo 3 generated an approximately 500 bp PCR product as shown in Figures $1 a$ and $b$. Sequence analysis of this PCR product showed an additional 196 bp to the original 563 bp partial sequence that had been previously obtained. The new sequence and the partial oleosin cDNA produced a contig sequence of about $759 \mathrm{bp}$.

The 5'- end region was further extended using two designed primers (Oleo 8 and 9). The results generated by these two primers were 200 and 150 bp PCR, respectively, as indicated in Figure $1 \mathrm{~b}$. The sequencing after cloning using $\mathrm{M} 13$ forward and reverse primers only achieved a $10 \mathrm{bp}$ extension at the 5' end giving the final consensus sequence at about $769 \mathrm{bp}$. The isolation of a partial cDNA sequence using the cDNA screening method obtained by Yong et al. (1999) is 550 bp. It is clearly shown that the RACE-PCR method used in the study is more efficient.

\section{Amplification of full length cDNA of oleosin by end- to-end PCR}

The end-to-end PCR method amplified $750 \mathrm{bp}$ fragment for each combination of primers are as illustrated in Figure 2. The bands were purified from the agarose gel and cloned into $\mathrm{pCR}^{\circledR} 4$-TOPO vector. The clones were 


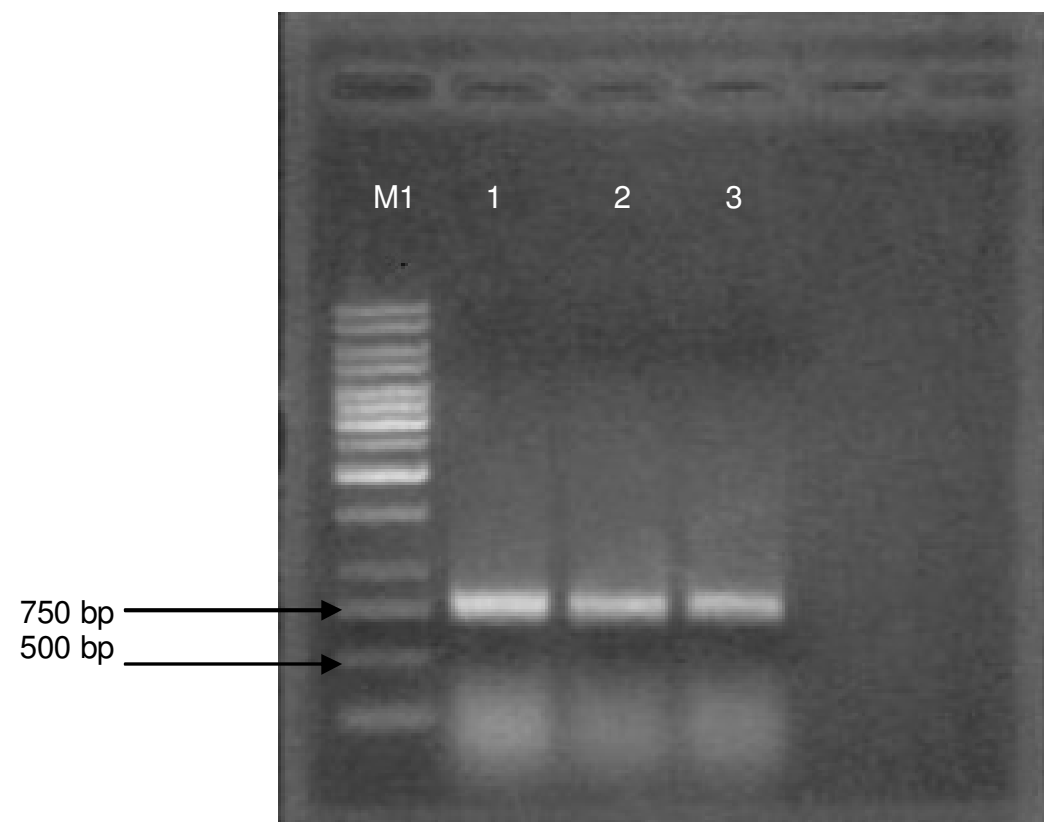

Figure 2. Agarose gel electrophoresis of end-to-end PCR product amplified from oil palm kernel using primers specific to oleosin cDNA. Lane M1: $1 \mathrm{~kb}$ GeneRuler DNA ladder, Lane 1: 750 bp PCR product (Oleo 13A and 15B), Lane 2: 750 bp PCR Product (Oleo 15A and 15B) and Lane 3: 750 bp PCR product (Oleo 16A and 15B).

Table 1. The significant matches of blastn analysis for cDNA of Oleosin from oil palm kernel.

\begin{tabular}{|l|l|c|c|c|}
\hline Genbank accession & \multicolumn{1}{|c|}{ Organism and gene } & Score & E value & Identity (\%) \\
\hline AF273023.1 & Elaeis guineensis oleosin (OPZE1A) mRNA & 886 & 0.0 & 99 \\
AF147758.1 & Elaeis guineensis oleosin (POPS115) mRNA & 886 & 0.0 & 98 \\
U43930.1 & Oryza sativa 16 kDa oleosin (ole16) mRNA & 284 & $4 \mathrm{e}^{-73}$ & 78 \\
X82678.1 & Hordeum vulgare Ole-2 mRNA for oleosin (low molecular weight) & 284 & $4 \mathrm{e}^{-73}$ & 78 \\
U13701.1 & Zea mays oil body protein 16 KDa oleosin (ole16) gene & 264 & $3 \mathrm{e}^{-67}$ & 77 \\
U72411.1 & Bromus secalinus 16 kDa oleosin (ole16) mRNA & 262 & $1 \mathrm{e}^{-66}$ & 74 \\
\hline
\end{tabular}

sequenced from both directions using M13 forward and reverse primers.

\section{Nucleotide sequence analysis}

The blastn results in Table 1 showed that the nucleotide sequence of oleosin cDNA from oil palm kernel was similar to the nucleotide sequence of low molecular weight isoforms of oleosin from rice (Oryza sativa), barley (Hordium vulgare), maize (Zea mays) and cheatgrass (Bromus secalinus).

Besides, the blastx results presented in Table 2 also showed that the amino acid sequence encoded by the oleosin cDNA from oil palm kernel exhibited high similarities with the low molecular weight isoform of oleosin cDNA from rice, maize, cheatgrass, barley and sesame seeds. Therefore, the cDNA of oleosin from oil palm kernel that had been isolated was predicted to be a low molecular weight isoform of oleosin.

\section{Conclusion}

5' RACE-PCR was successfully carried out using the gene specific-primers (Oleo 3, 8 and 9) to obtain the 5'end of the oleosin CDNA. The end-to-end PCR method managed to amplify the $750 \mathrm{bp}$ of complete cDNA sequence of oleosin. Both blastn and blastx analysis showed that the cDNA from the isolated oil palm kernel exhibited low molecular weight isoform of oleosin cDNA.

\section{ACKNOWLEDGEMENT}

The author would like to thank MPOB for all the support provided. 
Table 2. The significant matches of blastx analysis for cDNA of oleosin from oil palm kernel.

\begin{tabular}{|l|l|c|c|c|}
\hline \multicolumn{1}{|c|}{ Genbank accession } & \multicolumn{1}{|c|}{ Organism and gene } & Score & E Value & Identity (\%) \\
\hline AAF76238.1 & Oleosin [Elaeis guineensis] & 223 & $9 \mathrm{e}-57$ & 97 \\
AAD41080.1 & Oleosin [Elaeis guineensis] & 155 & $2 \mathrm{e}-36$ & 95 \\
AAC02239.1 & 16 kDa oleosin [Oryza sativa] & 144 & $7 \mathrm{e}-33$ & 67 \\
P13436 & Oleosin Zm-I (Oleosin 16 kDa) [Zea mays] & 137 & $8 \mathrm{e}-31$ & 65 \\
Q96543 & Oleosin 16 kDa [Bromus secalinus] & 134 & $4 \mathrm{e}-30$ & 63 \\
AAD42942.1 & $15 \mathrm{kDa}$ oleosin [Sesamum indicum] & 130 & $8 \mathrm{e}-29$ & 68 \\
CAA57995.1 & Low molecular weight oleosin [Hordeum vulgare] & 129 & $2 \mathrm{e}-28$ & 66 \\
\hline
\end{tabular}

\section{REFERENCES}

Altschul SF, Madden TL, Schaffer AA, Zhang J, Chang Z, Miller W and Lipman DJ (1997). Gapped BLAST and PSI-BLAST: A New Generation of Protein Database Search Programs. Nucleic Acids Res. 25: 3389-3402.

Ausubel FM, Brent R, Kingston RE, Moore DD, Seidman JG, Smith JA, Struhl K (1994). Current Protocols in Molecular Biology. New York: Greene Publishing Associates and Wiley-Interscience.

Davidson L (2006). Challenge the critics. Global Oils and Fats Business Magazine. pp. 12-15.

Huang AHC (1996). Oleosins and oil bodies in seed and other organs. Plant Physiol. 110: 1055-1061.

Hsieh K, Huang AHC (2004). Endoplasmic reticulum, oleosins, and oil in seeds and tapetum cells. Plant Physiol. 136: 3427-3434.

Li M, Murphy DJ, Lee KH, Wilson R, Smith LJ, Clark DC, Sung JY (2002). Purificationand structural characterization of the central hydrophobic domain of oleosin. J. Biol. Chem. 277: 37888-37895.

Maruyama K, Sugano S (1994). Oligo-Capping: A Simple Method to Replace the Cap Structure of Eukaryotic mRNAs with oligoribunucleotides. Gene 138: 171-174.
Murphy DJ, Vance J (1999). Mechanisms of lipid-body formation. Trends Biochem. Sci. 24: 109-115.

Murphy DJ (1993). Structure, function and biogenesis of storage lipid bodies and oleosins in plants. Progress Lipid Res. 32: 247-280.

Prescot A, Martin C (1987). A rapid method for the quantitative assessment of levels of specific mRNAs in plants. Plant Mol. Biol. Rep. 4: 219-224.

Rooijen GJH, Moloney MM (1995). Plant seed oil bodies as carriers for foreign proteins. Biol. Technol. 13: 72-77.

Sambanthamurthi R, Sundram K, Tan YA (2000). Chemistry and biochemistry of palm oil. Progress lipid Res. 39: 507-558.

Tzen JTC, Huang AHC (1992). Surface structure and properties of plant seed oil. J. Cell Biol. 117: 327-335.

Yong S, Yus of R, Koh CL, Cheah SC, Leslie CLO (1999). Partial nucleotide sequence of an oleosin cDNA from Elaeis guineensis Jacq. J. Oil Palm Res. pp. 18-23. 